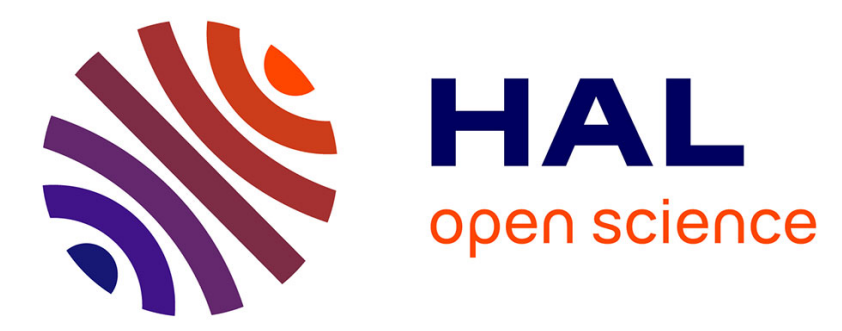

\title{
Tools for resistance monitoring in oriental fruit moth (Lepidoptera: Tortricidae) and first assessment in Brazilian populations
}

Myriam Siegwart, L.B. Monteiro, Sandrine Maugin, Jérôme Olivares, S. Malfitano Carvalho, Benoit B. Sauphanor

\section{To cite this version:}

Myriam Siegwart, L.B. Monteiro, Sandrine Maugin, Jérôme Olivares, S. Malfitano Carvalho, et al.. Tools for resistance monitoring in oriental fruit moth (Lepidoptera: Tortricidae) and first assessment in Brazilian populations. Journal of Economic Entomology, 2011, 104 (2), pp.636-645. 10.1603/EC10302 . hal-02651786

\section{HAL Id: hal-02651786 \\ https://hal.inrae.fr/hal-02651786}

Submitted on 29 May 2020

HAL is a multi-disciplinary open access archive for the deposit and dissemination of scientific research documents, whether they are published or not. The documents may come from teaching and research institutions in France or abroad, or from public or private research centers.
L'archive ouverte pluridisciplinaire HAL, est destinée au dépôt et à la diffusion de documents scientifiques de niveau recherche, publiés ou non, émanant des établissements d'enseignement et de recherche français ou étrangers, des laboratoires publics ou privés. 
Version définitive du manuscrit publié dans / Final version of the manuscript published in : Journal of Economic Entomology, 2011, vol.104, no.2, 636-645. DOI: 10.1603/EC10302

3 Tools for resistance monitoring in the oriental fruit moth (Lepidoptera: Tortricidae) and

\section{4 first assessment in Brazilian populations}

5

6

7 M. Siegwart ${ }^{1, *}$, L. B. Monteiro ${ }^{2}$, S. Maugin ${ }^{1}$, J. Olivares $^{1}$, S. Malfitano Carvalho ${ }^{3}$ and B.

8 Sauphanor $^{1}$

9

$10{ }^{1}$ INRA, UR 1115, Plantes et Systèmes de culture Horticoles, F-84000 Avignon, France ; ${ }^{2}$

11 Universidade Federal do Paraná, Departamento de Fitotecnia e Fitossanitarismo, 81531-990

12 Curitiba, Brazil; ${ }^{3}$ Universidade Federal de Lavras - UFLA, Departamento de Entomologia, 13 37200-000 Lavras, Brasil.

14 
Version définitive du manuscrit publié dans / Final version of the manuscript published in : Journal of Economic Entomology, 2011, vol.104, no.2, 636-645. DOI: 10.1603/EC10302

\section{Abstract}

In southern Brazilian apple orchards, predominantly organophosphates are used to control the oriental fruit moth, Cydia molesta Busck, but control failures often occur. Therefore the susceptibility of three C. molesta Brazilian populations was investigated to five insecticides of different groups and modes of action, in comparison with a susceptible laboratory strain mass reared in Southern France for over ten years. At the same time, comparative biochemical and genetic analysis were performed, assessing the activities of the detoxification enzymatic systems and sequencing a gene of insecticide molecular target to find out markers associated with resistance. The three Brazilian populations were significantly resistant to chlorpyrifos ethyl compared to the reference strain. One of the field populations, which had been frequently exposed to deltamethrin treatments, showed significant decreasing susceptibility to this compound, whereas none of the three populations had loss of susceptibility to tebufenozide and thiacloprid when compared to the reference strain. All three populations had slight but significant increases of Glutathione-S-transferase and carboxylesterases activities, and significant decrease of specific acetyl cholinesterase (AChE) activities compared to the reference. Only the most resistant population to chlorpyriphos exhibited a significantly higher mixed-function oxidase activity than the reference. The acetyl cholinesterase of females was significantly less inhibited by carbaryl in the Brazilian populations than in the reference strain (1.7- to 2.5-fold), and this difference was not expressed in the male moth. However, no mutation in the MACE locus was detected. These biological and molecular characterisations of adaptive response to insecticides in C. molesta provide tools for early detection of insecticide resistance in field populations of this pest.

Key words: Cydia molesta, insecticide resistance, monitoring, mechanism, target mutation 
Version définitive du manuscrit publié dans / Final version of the manuscript published in : Journal of Economic Entomology, 2011, vol.104, no.2, 636-645. DOI: 10.1603/EC10302

38

\section{Abstract in Portuguese}

Os inseticidas organofosforados são utilizados predominantemente para controle da mariposa oriental, Cydia molesta Busck em pomares de maçã na região Sul brasileira, mas ocorrem frequentemente perda de eficiência de controle. Portanto, a suscetibilidade de três populações brasileiras de C. molesta foi estudada a cinco inseticidas de diferentes grupos e modos de ação, comparando com população suscetível de laboratório criadas no sul da França há mais de dez anos. Ao mesmo tempo, foram realizados testes comparativos bioquímicos e análises genéticas, avaliando as atividades dos sistemas de desintoxicação enzimática e seqüenciamento de um gene, procurando encontrar marcadores associados à resistência. As três populações brasileiras foram significativamente resistente ao clorpirifós etil em comparação com a população de referência. Uma das populações de campo, que tinha sido freqüentemente expostos a deltametrina, apresentaram diminuição significativa de sensibilidade a este composto, ao passo que nenhum dos três populações apresentaram uma perda de susceptibilidade para tebufenozide e tiaclopride, quando comparada com a população de referência. As três populações apresentaram aumentos significativos de glutationa-S-transferase e atividades carboxilesterases e diminuiram a atividade de acetilcolinesterase (AChE) em relação à referência. Apenas a população mais resistente ao clorpirifós apresentou significativa atividade de oxidase de função mista em relação a referência. A acetilcolinesterase de fêmeas foi significativamente menos inibida por carbaryl na população brasileira do que na população de referência ( 1,7 a 2,5 vezes), e essa diferença não foi expressa em machos. No entanto, nenhuma mutação no locus MACE foi detectado. Estas caracterizações biológicas e moleculares, da resposta adaptativa de C. molesta aos inseticidas, fornece ferramentas para a detecção precoce da resistência em populações de campo.

Palavras chave: Cydia molesta, resistência a inseticida, monitoramento, mecanismo, mutação 
Version définitive du manuscrit publié dans / Final version of the manuscript published in : Journal of Economic Entomology, 2011, vol.104, no.2, 636-645. DOI: 10.1603/EC10302

61

The oriental fruit moth, Cydia molesta (Busk), is a damaging lepidopteran pest of peach tree (Prunus persicae (Linné)) orchards. C. molesta larvae attack both shoots and fruits of its native host plant, but this moth is also known to feed on quince (Cydonia oblonga (Mill.)), apricot (Prunus armeniaca (Linné)), almond (Prunus dulcis (Mill.)), medlar (Mespilus germanica (Bosc.)), and to a minor degree on cherry (Prunus cerasus (Linné)) and plum (Prunus domestica (Linné)) (Balachowsky 1966). Moreover, while this species was previously expected to migrate towards pome fruits in the late generations after the harvest of stone fruits, C. molesta has acquired the ability to complete its life cycle on American and European pome fruit orchards and is causing heavy damages on apple and pears (Reis et al. 1988, Usmani and Shearer 2001, Natale et al. 2003).

In South Brazil C. molesta is present since the early 1980s (Lorenzato 1988), and its damages were first recorded in Vacaria (Rio Grande do Sul) and Fraiburgo (Santa Catarina) then during the 90's in São Joaquim (Santa Catarina) and Porto Amazonas (Paraná). The control of $C$. molesta in Brazil involved exclusively neurotoxic insecticides including numerous organophosphates until the end of 1990s. Tebufenozide and novaluron are the only insect growth regulators registered against C. molesta in Brazil (Andrei 2009). These insecticides are aimed to control simultaneously C. molesta and secondary pests, including Anastrepha fraterculus (Wiedemann) (Diptera: Tethritidae) and Bonagota cranaodes (Meyrick) (Lepidoptera: Tortricidae) (Botton et al. 2000).

In Brazilian apple orchards and in South-European peach tree orchards as well, the protection against C. molesta requires up to ten treatments per year (Monteiro et al. 2009, Siegwart 2010). Despite this high insecticide pressure, control failures were recorded in several locations of both production areas during the last two years (Monteiro and Souza 2010, Monteiro et al. 2009, 
Version définitive du manuscrit publié dans / Final version of the manuscript published in : Journal of Economic Entomology, 2011, vol.104, no.2, 636-645. DOI: 10.1603/EC10302

Siegwart 2010b). This could be the result of the selection of insecticide resistance, as it already occurred for organophosphates and carbamates in North American populations of C. molesta (Kanga et al. 1997, Pree et al. 1998).

Insecticide resistance management requires a discontinuous selection process, which may be obtained from the use of non-chemical control methods (Roush and Tabashnik 1990, Monteiro et al. 2008) or by alternating insecticide compounds with different modes of action. The implementation of new compounds is thus of interest to counter the selection of resistance to neurotoxic compounds that may result from their intensive and often exclusive use in Europe (mainly pyrethroids) or in South America (mainly organophosphates). New necotinoid and insect growth regulator families could be interesting tools, due to the fact that several neurotoxic active ingredients are withdrawn from European and South American registration.

Early detection of insecticide resistance is also needed to avoid the rapid spread of this phenomenon and to allow the implementation of resistance management strategies (Kanga et al. 2003). Studies on the North American population showed an increase of Esterase in resistant populations compared to the susceptible ones, along with a decreased inhibition of acetylcholine esterase by carbamates and organophosphates (Kanga et al. 2003), indicating a probable mutation in this enzyme gene.

In this study, the resistance status of Brazilian populations of $C$. molesta collected in more or less intensively sprayed orchards was investigated to five active ingredients from different insecticide families: (i) neonicotinoid, (ii) pyrethroid, (iii) moulting activating compound (MAC), (iv) carbamate and (v) organophosphate (OP). Bioassays were paired with metabolic analysis and gene sequencing of insecticide molecular targets, to identify markers associated with the resistance to these different insecticide groups. Enzyme assays were designed to assess the 
Version définitive du manuscrit publié dans / Final version of the manuscript published in : Journal of Economic Entomology, 2011, vol.104, no.2, 636-645. DOI: 10.1603/EC10302

107

activity of three systems involved in insecticides detoxication in numerous insect pests:

Glutathione S-transferases (GST), mixed function oxydases (MFO) and carboxylesterases (EST)

(Yasutomi 1983, Oppenoorph 1985). The total acetylcholine esterase activity which may vary resulting in resistance to organophosphates or carbamates (Zhu and Gao 1999) was estimated. Finally, genes coding for the two forms of acetylcholine esterase (AChE) were partially sequenced. The whole methodology was designed to define molecular and multi-metabolic diagnostic tools to investigate the combination of mechanisms involved in resistance phenomenon.

\section{Material and methods}

\section{Insects}

Three Brazilian populations of C. molesta were sampled in apple orchards in Vacaria (Rio Grande do Sul state), Lages (Santa Catarina state), and Porto Amazonas (Paraná state). A susceptible laboratory strain $\left(\mathrm{S}_{\mathrm{it}}\right)$ originating from Italian peach tree orchards (Provided by Fabio Molinari, University of Piacenza, Italy) was used as reference. The Vacaria population was collected in 2005 and reared in the laboratory on artificial diet (Guennelon et al. 1981) during 3 years with two further introductions of new genetic material from the same orchard. This orchard had mainly been protected using pyrethroid and organophosphate applications previous to collecting the population. The other two Brazilian populations were field collected in early 2008 in orchards where failure of chemical protection occurred. In 2006/2007 season five OPs were applied in Porto orchard while Lages received seven organophophates and two MAC. Close to $10 \%$ damages were recorded in 2007 in Lages orchard despite this protection program (unpublished data). Porto and Lages populations were reared in Parana Federal University, Curitiba (Brazil) during two generations. The three Brazilian populations were then transferred at 
Version définitive du manuscrit publié dans / Final version of the manuscript published in : Journal of Economic Entomology, 2011, vol.104, no.2, 636-645. DOI: 10.1603/EC10302

INRA Avignon, where analyses were performed. These analyses were completed during three successive generations, required to multiply the insects and for preliminary tests to set the adequate concentrations of the different insecticide and the methodology of enzyme analysis. The rearing of the field populations and of the reference strain was conducted at $25 \pm 1^{\circ} \mathrm{C}, 70 \%$ RH under 16 L: 8 D photoperiod. Egg laying was obtained in plastic tubes (8cm in diameter, 20 cm long) closed on both sides with gaze. Eggs were placed on artificial diet (Guennelon et al $1981)$ in a plastic container $(30 \times 14 \times 10 \mathrm{~cm})$ for larval development. Larvae pupated in gaze strips, in plastic containers. The reference strain $S_{i t}$ had been mass reared on artificial diet for 10 years in Crop Protection Service of Lyon (France), without any insecticide exposure.

\section{Insecticides}

Susceptibility of the populations to the OP: chlorpyrifos-ethyl (Pyrinex ME, $250 \mathrm{~g} / \mathrm{l}$, Makhteshim-Agan France), to the neonicotinoid: thiacloprid (Calypso, 480 g/l, Bayer CropScience France), to the pyrethroid: deltametrin (Decis, $15 \mathrm{~g} / \mathrm{l}$, Bayer CropScience France), to the carbamate: carbaryl (Sevin, $85 \%$ wetable powder, Certis France) and to the benzhydrazid: tebufenozide were assessed. Fresh dilutions of formulated insecticides were prepared in distilled water for bioassays on neonates.

\section{Bioassays}

Microplate (96-wells, Sterilin ${ }^{\circledR}$ ) wells were filled with $150 \mu \mathrm{L}$ of artificial diet (Stonefly Industries Ltd, Rochester, NY), and $6 \mu \mathrm{L}$ of each insecticide solution were applied to the diet's surface according to Reyes and Sauphanor (2008). For each population, concentration-response relationships were established per insecticide. Six concentrations giving between 0 and $100 \%$ mortality were used. Distilled water replaced insecticide in the control (Fuentes-Contreras et al. 2007). Newly hatched larvae (0-4 h old) were individually placed in the wells. Mortality was 
Version définitive du manuscrit publié dans / Final version of the manuscript published in : Journal of Economic Entomology, 2011, vol.104, no.2, 636-645. DOI: 10.1603/EC10302

153

154

recorded after 7 days at $25^{\circ} \mathrm{C}$. A larva was considered as dead when not responding to a probe with dissecting forceps. Missing larvae (a mean of $1.6 \%$ in the whole experiment) were subtracted from the initial number.

\section{Enzymatic activities}

Glutathione S-transferase (GST), mixed-function oxidase (MFO), esterase (EST) and acetylcholine esterase (AChE) activities were evaluated on adult (head for AChE activity and inhibition, abdomen for MFO and thorax for other enzymes). At least 12 insects per sex and per population were analysed for each enzymatic system. Fluorescence and absorbance were measured using a microplate reader (HTS 7000, Perkin Elmer). In order to obtain activities of the three enzyme systems on each insect, each part of adult body was used as specific enzyme extract.

Enzyme extracts. EST and GST activities were evaluated using single thorax homogenized in $110 \mu 1$ of $50 \mathrm{mM}$ Hepes buffer ( $\mathrm{pH} 7$ ). For AChE activity, one head was homogenized on ice in $50 \mu 1$ of $50 \mathrm{mM}$ phosphate buffer with $0.5 \%$ Triton (pH 7.2). For AChE inhibition five heads of adults were pooled and homogenized in $250 \mu 1$ of ice-cold phosphate buffer $(0.05 \mathrm{M} ; \mathrm{pH} 7.2)$ containing $0.5 \%$ Triton. The homogenates obtained from each insect segment were centrifuged at $15000 \times \mathrm{g}$ for $15 \mathrm{~min}$ at $4^{\circ} \mathrm{C}$, and the supernatants were used as enzyme sources (Bouvier et al. 2002). The protein content of each sample was measured (Bradford 1976) using bovine serum albumin to build the standard curve.

Glutathione S-transferases. GST activity was determined in black microplates (96-wells, Costar®) using monochlorobimane (MCB) as substrate (Nauen and Stumpf 2002). The reaction mixture in one well consisted of $30 \mu 1$ of enzymatic extract, $170 \mu 1$ of a solution containing: $6 \mu 1$ of $100 \mathrm{mM}$ glutatione (GSH), $162 \mu 1$ of Hepes buffer (50mM, pH7.0) and $2 \mu \mathrm{L}$ of $30 \mathrm{mM} \mathrm{MCB}$. 
Version définitive du manuscrit publié dans / Final version of the manuscript published in : Journal of Economic Entomology, 2011, vol.104, no.2, 636-645. DOI: 10.1603/EC10302

Wells with Hepes buffer instead of enzyme extract were used as controls. Fluorescence was measured after 20 min incubation at $22^{\circ} \mathrm{C}$, with $380 \mathrm{~nm}$ excitation and $450 \mathrm{~nm}$ emission filters. Since the bimane-glutathione adduct was not commercially available, the activity was expressed as fluorescence units per min per $\mu \mathrm{g}$ of total protein extracted.

Esterases. Total non-specific EST activity was measured with $\alpha$-naphthyl acetate $(\alpha-\mathrm{NA})$ and para nitrophenyl acetate (p-NA) as substrates (Reyes et al, in press). The reaction mixture for the first substrate was $1 \mu 1$ of protein extract and $194 \mu 1$ of $30 \mu \mathrm{M} \alpha-\mathrm{NA}$ in Hepes buffer $(50 \mathrm{mM}, \mathrm{pH}$ 7.0) in each microplate well. The reaction was stopped and coloured after 20 min incubation at $22^{\circ} \mathrm{C}$ in darkness, by adding $55 \mu 1$ of $0.2 \%$ Fast garnet GBC in $2.5 \%$ sodium dodecyl sulphate solution. Absorbance was recorded at 590nm, after incubation during $20 \mathrm{~min}$ in darkness at room temperature.

The reaction mixture for the second substrate was $2.5 \mu 1$ of protein extract, $2.5 \mu 1$ of p-NA (50 $\mathrm{mM}$ in DMSO) in $245 \mu 1$ of Hepes buffer $(50 \mathrm{mM}$, pH 7) with EDTA $(1 \mathrm{mM})$ in each well. Absorbance was recorded at $405 \mathrm{~nm}$ each minute (kinetic mode) during 10min. If the stabilisation of speed reaction occurred, the difference of OD per min was calculated, otherwise the measurement was repeated. Two standard curves with $\alpha$-Naphtol $(0-18 \mathrm{nmoles} /$ well $)$ or $p$ nitrophenol (0-37.5nmoles/well) were elaborated to express activity in nmoles of product $/ \mathrm{min} / \mathrm{mg}$ of total proteins.

Mixed-function oxidases. The MFO activity was determined using 7-ethoxycoumarin Odeethylation (ECOD) (Ulrich 1972) adapted for in vivo analysis in microplate. Twenty four fresh insects of each strain were analysed. Adult abdomens were dissected and homogenised in incubation solution: $100 \mu \mathrm{l}$ of Hepes buffer $(50 \mathrm{mM} \mathrm{pH} 7)$ with 7-ethoxycoumarin $(0.4 \mathrm{mM})$; on ice and centrifuged at $15000 \times \mathrm{g}$ for $2 \min$ at $2^{\circ} \mathrm{C}$. Supernatants were individually placed in 
Version définitive du manuscrit publié dans / Final version of the manuscript published in : Journal of Economic Entomology, 2011, vol.104, no.2, 636-645. DOI: 10.1603/EC10302

wells of black microplates (96-wells, Costar $($ ) $)$. After $4 \mathrm{~h}$ incubation at $30^{\circ} \mathrm{C}$, the reaction was stopped by adding $100 \mu \mathrm{L}$ of $1.5 \mathrm{M}$ glycine buffer (pH 10.3). The 7-hydroxycoumarin (HC) fluorescence was quantified with $380 \mathrm{~nm}$ excitation and $465 \mathrm{~nm}$ emission filters. Four wells receiving glycine buffer previous to incubation were used as control. The activity was expressed as pg of 7-HC/insect/min thanks to a standard curve of 7-Hydroxycoumarine (0.5-4.5 nmoles/well).

Acetylcholine esterase. The AChE activity was determined using acetylthiocholine (ASCh) as substrate (Ellman et al. 1961). To analyse numerous samples, Ellman's protocol was adapted for microplate analysis. The enzyme activity was measured by increase of yellow coloration due to the formation of thionitrobenzoate, based on the following reactions:

Acetylthiocholine (ASCh) $\stackrel{\text { (Enzyme) }}{\longrightarrow}$ Thiocholine + acetate

Thiocholine + Dithiobisnitrobenzoate (DTNB) $\longrightarrow$ Thionitrobenzoate (yellow color) Nineteen to 40 insect extracts were analysed per sex and population. The reaction mixture in one well was composed of $138.5 \mu 1$ of phosphate buffer $(0.1 \mathrm{M}, \mathrm{pH} 8.0), 5 \mu 1$ of DTNB $0.01 \mathrm{M}(0.3$ $\mathrm{mM}$ final concentration), $1.5 \mu \mathrm{ASCh} 0.1 \mathrm{M}(1 \mathrm{M}$ final concentration) and $5 \mu 1$ of protein extract. Four wells receiving phosphate buffer $(0.1 \mathrm{M}, \mathrm{pH} 8)$ instead of protein extract were used as control. Absorbance was recorded at $405 \mathrm{~nm}$ every minute (kinetic mode) during $10 \mathrm{~min}$. When the reaction speed was stabilized, the activity was calculated and expressed in nmoles of Thiocholine/min/mg of total protein thanks to a standard curves with DTT (0-4.5 nmoles/well) instead of thiocholine (Ellman et al. 1961). As DTT has two functional groups -SH this standard curve has to be divided by two before using.

The inhibition of AChE activity by carbaryl was assessed using 25 insects per sex and population. $20 \mu \mathrm{l}$ of carbaryl dissolved in ethanol was placed in each well of a microplate, and the 
Version définitive du manuscrit publié dans / Final version of the manuscript published in : Journal of Economic Entomology, 2011, vol.104, no.2, 636-645. DOI: 10.1603/EC10302

solvent was evaporated to dryness before addition of reaction mixture. Preliminary studies were conducted to estimate the representative range of insecticide concentrations. On this prepared plate, $10 \mu 1$ of extracts were incubated at $4^{\circ} \mathrm{C}$ during $20 \mathrm{~min}$. In the control wells the insecticide was replaced by the solvent alone and in the blank by $0.01 \mathrm{M}$ of Eserine. The reaction was initiated by addition of a solution containing $133.5 \mu 1$ of phosphate buffer $(0.1 \mathrm{M}, \mathrm{pH} 8), 5 \mu \mathrm{l}$ of DTNB $0.01 \mathrm{M}(0.3 \mathrm{mM}$ final concentration $)$ and $1.5 \mu$ ASCh $0.1 \mathrm{M}(1 \mathrm{M}$ final concentration $)$. The absorbance was recorded every $5 \mathrm{~min}$ for a total period of $40 \mathrm{~min}$. Three replicates of seven concentrations were used in each test. Concentration of insecticides causing 50\% inhibition (IC50) of AChE activity were estimated though probit analysis (Russell et al. 1977). Difference in inhibition among genotypes were considered not significant if the $95 \% \mathrm{CL}$ of the inhibition ratio at the IC 50 level of the susceptible strain included 1.0 (Robertson and Preisler 1992).

\section{Sequencing the molecular targets of insecticides}

Eight individuals were sequenced for ace1: one from $\mathrm{S}_{\mathrm{it}}$, one Porto, two Vacaria and two Lages the last two are a Porto and a Vacaria survival of biotests at 1200ppm of chlorpirifos. Theses last two individual are used to sequence ace2 gene.

We performed the total DNA extraction of C molesta using a hexadecyl-trimethyl-ammonium bromide (CTAB) protocol (Murray and Thompson 1980). Adults were individually ground in $200 \mu 1$ of proteinase $\mathrm{K}(0.3 \mathrm{mg} / \mathrm{ml})$ and incubated over night at $56^{\circ} \mathrm{C}$. Lysis occured at $65^{\circ} \mathrm{C}$ during $1 \mathrm{~h}$ by adding $300 \mu \mathrm{l}$ of lysis buffer (Tris-HCl 200mM, EDTA 50mM, NaCl 2M, CTAB $2 \%$ ) and $100 \mu 1$ of sarcosyl $5 \%$. Proteins were precipitated and separated by chlorophormisoamylalcohol (24:1) treatment. Nucleic acids were precipitated at $-20^{\circ} \mathrm{C}$ after adding one volume of isopropanol. DNA pellet was washed in ethanol and resuspended in $60 \mu \mathrm{l}$ of water. PCR amplifications were carried out in a $25 \mu \mathrm{L}$ reaction volume containing, $1 \mathrm{X}$ GoTaq buffer 
Version définitive du manuscrit publié dans / Final version of the manuscript published in : Journal of Economic Entomology, 2011, vol.104, no.2, 636-645. DOI: 10.1603/EC10302

(Promega), $200 \mu \mathrm{M}$ of each dNTPs, $0.4 \mu \mathrm{M}$ of each primer, one Unit of GoTaq and $2 \mu 1$ of DNA template.

For amplification in the first gene of AChE (ace1), we used primers: ACE 1S (5'cccagacctgttgaaagctg-3') and ACE 1R (5'-tgctctctggtaatgcctacg-3') and for amplification in the second gene (ace2) we used primers: ACE 2S (5'-gtgccgcagcatttaagagt-3') and ACE 2R (5'tgccttccttcatcattgtg-3')

Thermal conditions were : $94^{\circ} \mathrm{C}$ for $3 \mathrm{~min}$, followed by 35 cycles of $94^{\circ} \mathrm{C}$ for $30 \mathrm{~s}, 55^{\circ} \mathrm{C}$ for $60 \mathrm{~s}$ and $74^{\circ} \mathrm{C}$ for $2 \mathrm{~min}$. For ace 1 , primers were designed using a sequence of the related tortricid moth Cydia Pomonella L (Lepidoptera: Tortricidae). This sequence name is cydpom-ace1, noted in the GenBank database under the accession number DQ267977 (Cassanelli et al. 2006). For ace 2 the cDNA sequence of the gene (accession number: HM775184) was provided by S.

Cassanelli (University of Modena and Reggio Emilia, Italie).

The PCR fragments obtained were purified after visualisation using $1 \%$ agarose gel with the QIAquick ${ }^{\circledR}$ Gel Extraction Kit and directly sequenced (Genome express, Meylan, France). Data analysis was performed with the BioEdit software (Tom Hall, Carlsbad, US).

\section{Statistical analyses}

A probit analysis on corrected mortalities (Abbott 1925) was done to determine the LC50 values (Raymond 1985). Resistance ratios at the LC50 (RR50, which is the ratio between the LC50 of the resistant strain and the LC50 of the susceptible strain) and their 95\% CL were calculated. The LC50s were considered different when the $95 \%$ CL of their $\mathrm{RR}_{50}$ did not include 1 . Biochemical data were subjected to analysis of variance (ANOVA). Means were compared by the protected least significant difference Tukey test $(\mathrm{P}<0.05)$ using the software $\mathrm{R}($ Bell Laboratories, Murray Hill, US). 
Version définitive du manuscrit publié dans / Final version of the manuscript published in : Journal of Economic Entomology, 2011, vol.104, no.2, 636-645. DOI: 10.1603/EC10302

\section{Results}

\section{Laboratory bioassays}

The three Brazilian populations tested were significantly less susceptible to chlorpyriphos than the European reference strain $\mathrm{S}_{\mathrm{it}}$, with $\mathrm{RR}_{50}$ ranging from 2.70 to 2.98 (Table 1). The Vacaria population was also significantly resistant to deltamethrin $\left(\mathrm{RR}_{50}=1.80\right)$ while the two other populations were not. Vacaria population was also the less susceptible to carbaryl, with $1.00-$ 2.08 values of the $95 \%$ CL of its $\mathrm{RR}_{50}$ (Table 1 ). Surprisingly, two populations were significantly less susceptible to thiacloprid than the reference strain $\left(\mathrm{RR}_{50}=0.61\right.$ and 0.43 for Vacaria and Porto, respectively), and the Lages population was two times less susceptible to tebufenozide than $\mathrm{S}_{\mathrm{it}}\left(\mathrm{RR}_{50}=0.48\right)$.

Despite differences in their selection pressure, the three Brazilian codling moth populations did not exhibit strong differences in their insecticide susceptibility. All of them responded similarly to chlorpyriphos ethyl. However the Vacaria population was 2-fold less susceptible to deltamethrin than Porto and Lages (Vacaria vs Porto $\mathrm{RR}_{50}=2.04$ (1.32 -3.16); Vacaria vs Lages $\left.\mathrm{RR}_{50}=1.96(1.27-3.05)\right)$. In the same way, Porto population was $2.19(1.60-2.99)$ times more susceptible to thiacloprid than Lages, and Lages was $2.04(1.53-2.72)$ times more susceptible to tebufenozide than Vacaria .

\section{Enzymatic activities}

The three Brazilian populations exhibited significantly higher GST activities than the Sit strain $(F=34.11, \mathrm{df}=39, P<0.001, F=25.34, \mathrm{df}=43, P<0.001, F=15.95, \mathrm{df}=45, P<0.001$ for

Lages, Porto and Vacaria, respectively) (Figure 1a). The highest enzymatic ratio was obtained between Lages and $\mathrm{S}_{\mathrm{it}}$ strain (1.7 fold). No sex-linked variability was observed for this enzyme 
Version définitive du manuscrit publié dans / Final version of the manuscript published in : Journal of Economic Entomology, 2011, vol.104, no.2, 636-645. DOI: 10.1603/EC10302

system $(F=2.309, \mathrm{df}=1, P=0.133)$ (Data not shown). EST activities measured using both $\alpha$ NA and p-NA substrates followed similar patterns as GST activity (Figure 1b), with significantly higher values in the three Brazilian populations than in the $S_{i t}$ strain $(F=29.060$, df $=40, P<$ $0.001 ; F=35.112, \mathrm{df}=44, P<0.001 ; F=14.914, \mathrm{df}=46, P<0.001$ with $\alpha-\mathrm{NA}$ for Lages, Porto and Vacaria, respectively; $F=31.400, \mathrm{df}=39, P<0.001 ; F=29.863$, df $=43, P<0.001$; $F=17.512, \mathrm{df}=43, P=0.001$ with $\mathrm{p}-\mathrm{NA}$ for Lages, Porto and Vacaria, respectively). The highest enzymatic ratio was between Lages and $S_{i t}$ strain: 2.0 fold for $\alpha-N A$ and 1.7 fold for $p-$ NA. The Lages populations, collected in orchards where failure of chemical protection occurred, had higher GST and a-NA activities than the Vacaria population while the Porto population exhibited intermediate activities for both enzyme systems. These three populations did not differ significantly from each other for p-NA EST activities.

A different pattern was observed for specific acetylcholine esterase activity, with a significantly higher activity in the $\mathrm{S}_{\mathrm{it}}$ strain than in Brazilians populations $(F=87.4077, \mathrm{df}=211, P<0.001)$. But as for GST and EST enzyme systems, the Vacaria population exhibited a lower specific AChE activity than Porto and Lages $(F=50.9626, \mathrm{df}=105, P<0.0001$ and $F=27.4031$, $\mathrm{df}=$ $126, P<0.0001$, respectively) (Figure 1c). No sex-linked variability was observed for AChE activities $(F=0.375, \mathrm{df}=211, P=0.5410$,$) .$

Only the Lages population had significantly higher MFO activity than the $\mathrm{S}_{\mathrm{it}}$ strain $(F=7.7$, df $=$ $46, P=0.008$,). Moreover, activity ratio is low (1.4-fold), and the three Brazilian populations did not differ significantly from each other for this character. All tested females exhibited a higher MFO activity than males $(F=11.3, \mathrm{df}=84, P<0.002$ ) (Figure 2$)$, due to their significant bigger size (data not shown). This difference was verified whatever the population $\left(\mathrm{S}_{\mathrm{it}}: \mathrm{T}=7.9, \mathrm{df}=22\right.$, $P<0.001$; Porto: $\mathrm{T}=18.2, \mathrm{df}=22, P$ 0.001; Vacaria: $\mathrm{T}=10.9, \mathrm{df}=15, P<0.005$; Lages: $\mathrm{T}=$ 
Version définitive du manuscrit publié dans / Final version of the manuscript published in : Journal of Economic Entomology, 2011, vol.104, no.2, 636-645. DOI: 10.1603/EC10302

$8.2, \mathrm{df}=22, P<0.001)$. The inhibition of the AchE activity by carbaryl was significantly lower in the Brazilan population than in the $S_{\text {it }}$ strain, excepted for the males of the Vacaria population (Table 2). The AChE of Lages population was also less susceptible to the inhibition by carbaryl than that of Vacaria moths.

\section{Gene sequencing of acetylcholinesterase}

Parts of the two AChE genes (ace1 and ace2) were sequenced for the first time in C. molesta in order to search for a mutation potentially involved in organophosphate resistance. No differences were found between the four oriental fruit moth populations in the $850 \mathrm{pb}$ segments of ace1 gene that were sequenced (AN in GenBank:HM775185). 74 points differences were found between the DNA sequences of C. molesta and C. pomonella, three of them being responsible of protein variation : I168V ; P272A and I369T (Numbers correspond to C. pomonella (numbering DQ267977)). These three variant amino acids exist in other species. They are presumably not involved in the enzyme conformation and activity. The second gene knows to code acetylcholinesterase in Cydia genus, ace 2 was partially sequenced in individuals showing high tolerance to chlopyrifos in our bioassays (AN in GenBank: HM775184). But none sequences differences was found between our $\mathrm{S}_{\mathrm{it}}$ strain and this individuals.

\section{Discussion}

The first aim of this study was to set up in C. molesta a method previously developed in $C$. pomonella allowing the early detection of insecticide resistance in field populations (Reyes and Sauphanor 2008). This was achieved through the implementation of bioassays with targeted insecticides, enzymatic diagnostic based on the main systems involved in insecticide metabolization and sequencing of the molecular target of organophosphates. 
Version définitive du manuscrit publié dans / Final version of the manuscript published in : Journal of Economic Entomology, 2011, vol.104, no.2, 636-645. DOI: 10.1603/EC10302

The microplate bioassay on neonates already described for C. pomonella (Reyes and Sauphanor 2008) proved appropriate for C. molesta and provided reliable results for the five tested insecticides, highlighting small but significant differences between the tested populations and the reference susceptible strain. The three Brazilian populations exhibited a higher tolerance to chlopryriphos than the reference strain $S_{i t}$, in coherence with the frequent applications of organophosphorous insecticides in Brazilian orchards to prevent C. molesta injury. Such reduced susceptibility to organophosphates may partially explain the heavy damages on fruits caused in these orchards by C. molesta during the last five years. On the other hand, Vacaria population was significantly more tolerant to deltamethrin than Porto and Lages, probably due to the fact that pyrethroïds were more frequently used before the year 2000 than nowadays. Indeed Vacaria is one of the oldest and the largest growing area for apple orchards in Brazil, planted in the beginning of 1980. Lages and Porto orchards were planted more recently, in 1990 and 1998, respectively, and therefore received only few pyrethroid treatments during their production period.

In our study the reliability of the reference strain has to be considered carefully. It was collected in Italy over 15 years ago in an untreated peach tree orchard, and was then maintained in continuous mass rearing in the laboratory without any selection pressure. It is thus expected to be susceptible to insecticides, but also to have a genetic background strongly different from the populations more recently sampled, in apple orchards of a distant continent. All our populations had been reared on artificial diet for a few generations in the same conditions previous to the study, avoiding the differential induction of digestive enzymes by the host plants. However we cannot exclude that the differences of enzyme activities recorded between the field populations 
Version définitive du manuscrit publié dans / Final version of the manuscript published in : Journal of Economic Entomology, 2011, vol.104, no.2, 636-645. DOI: 10.1603/EC10302

and the reference result from these distant genetic backgrounds rather than from an adaptive response to the insecticide pressure. The response to insecticide and the enzyme activities were often observed to be under dependence on the host plant, as demonstrated for the susceptibility of Epiphyas postvittana (Lepidoptera: Tortricidae) to organophosphates (Robertson, et al. 1990). The comparison of the responses to insecticides and of biochemical characteristics between the three Brazilian populations is thus meaningful.

The three Brazilian populations exhibited a reduced susceptibility to chlorpyriphos compared to the reference strain, together with a decreased specific activity of the AChE target of Ops and carbamates. It is noticeable that the Vacaria population owning the lowest specific AChE activity was also the less susceptible to carbaryl. Similar OP resistance associated to reduced AChE's affinity for acetylthiocholine substrate was previously described in C. pomonella (Reuveny et al 2004). This resistance to chlorpyriphos in OFM populations was also associated with an increase of GST and EST (for both a-NA and p-NA substrates) activities. However, converging to what occurs in C. pomonella (Reyes et al, in press), these combined target site modification and detoxification mechanisms do not confer a high level of resistance to the analyzed pesticides. But in the case of these OFM populations, the activity ratios of the detoxifying enzymes were rather low, never exceeding two times more than the reference. The Brazilian populations also slightly differed from the reference strain for their specific AChE activity (0.4- to 0.7-fold) and for AChE's inhibition by carbaryl (1.7- to 2.5-fold in female moths). Comparatively, the 25-fold resistance to carbofuran of Canadian populations of C. molesta (Kanga et al. 1997) was associated to a close to 4-fold increase of a-NA and to a 1757- fold decrease of susceptibility of AChE to carbaryl, without any alteration of the MFO and GST activities. Further investigations 
Version définitive du manuscrit publié dans / Final version of the manuscript published in : Journal of Economic Entomology, 2011, vol.104, no.2, 636-645. DOI: 10.1603/EC10302

attributed this resistance to organophosphates and carbamates of North American populations of C. molesta to a sex-linked alteration of AChE (Kanga et al. 1997, de Lame et al. 2001, Schearer and Usmani 2001). The small differences of specific AChE activity and of inhibition by carbaryl observed in our samples could also be the result of a mutation or of a modified expression of the ace gene in some individuals. We therefore focused on qualitative or quantitative modifications of the gene, more precisely on the section where a mutation MACE was described in C. pomonella (Cassanelli et al. 2006). The sequencing did not reveal any modification in this part of the gene, but a modification can be localised in another section of the gene. Moreover, only eight insects could be sequenced at this step, and we thus have now to develop a routine test to screen entire populations. Moreover, although the basic blueprint of life is encoded in DNA, the execution of the genetic plan is carried out by the activities of proteins. The fabric of biological diversity is therefore protein-based and natural selection acts at the protein and phenotypic level (Karr 2008, Biron et al. 2010). Another hypothesis to test is that C. molesta resistance is caused by post-transcriptional changes by using transcriptomics and proteomics tools (Biron et al. 2006, Nedelkov et al. 2006, Karr 2008).

None of the observed mechanisms could explain the resistance to deltamethrin in Vacaria population, which was significant when compared to the reference strain and with the two other Brazilian populations as well. Compared to these two populations, Vacaria had the lowest GST and MFO activities, and also expressed the lowest affinity for both EST substrates. Such specific resistance to deltamethrin could thus be the result of a mutation in the target site of pyrethroids, the voltage-dependant sodium channel, as previously demonstrated in numerous insect species including C pomonella (Brun Barale et al 2005, Reyes et al 2007) and also suspected in French 
Version définitive du manuscrit publié dans / Final version of the manuscript published in : Journal of Economic Entomology, 2011, vol.104, no.2, 636-645. DOI: 10.1603/EC10302

populations of C. molesta (Siegwart et al 2010a). The sequencing of this gene in C. moletsa would thus be of particular interest, to go back to the conserved DNA samples of Brazilian and French populations.

The Lages population issuing from the orchard which was the most heavily treated during in the last five years had also the highest GST and EST activities, significantly higher than the Vacaria population, and had also an increased MFO activity when compared to the reference strain. Such activities were not related to an increased tolerance to any of the tested insecticides but conversely to a significantly increased susceptibility to tebufenozide. An increased susceptibility to thiacloprid was also recorded in Lages and Porto populations, without any relation with the observed mechanisms. Regarding the low resistance and activity ratios that were recorded in this study, it may be hypothesized that resistance mechanisms are at the beginning of the selection process, as attested by the large intra population variability and the high activities recorded in few individuals of the population issuing from the most heavily treated orchard in Lages.

Moreover, it cannot be excluded that a part of the resistance was lost during the few generations of rearing of the populations in the laboratory without selection pressure, due to the fitness cost usually associated to metabolic resistances (Roush and Plapp 1982, Mc Kenzie and Batterham 1991, Boivin et al. 2003) and to the AChE mutations as well (Bourguet et al 2004, Shi et al 2004). However this loss of resistance during the rearing process could only lead to an under estimation of the rate of resistant individuals in the analysed populations, without qualitative change in the observed mechanisms.

Establishing the baseline susceptibility to insecticides and the baseline activity of enzymatic metabolization systems is required for insecticide resistance monitoring and management (Roush and Tabashnik 1990). This was made possible with this study for insecticide groups which were 
Version définitive du manuscrit publié dans / Final version of the manuscript published in : Journal of Economic Entomology, 2011, vol.104, no.2, 636-645. DOI: 10.1603/EC10302

429 the most intensively used in apple orchards during previous decades, i.e. organophosphates, pyrethroids and carbamates. Due to their negative ecological impact, these compounds are now

431 being replaced by more selective or new ones, including insect growth regulators and neonicotinoids. Despite the frequent observation of metabolic resistance to the moulting activator 433 tebufenozide in various lepidopteran species (Sauphanor and Bouvier 1995, Smagghe et al. 1998, 434 Waldstein and Reissig 2000, Cao \& Han 2006), the efficacy of this insecticide was conserved 435 against the tested populations. This is also the case for thiacloprid, which is not yet frequently 436 applied in the studied area. The developed and tested method will be used to analyse new 437 populations, trying now to get large collections allowing direct investigations on the F1 neonates 438 of the sampled insects. This method will also be implemented for other insecticides, including the recent compounds that are expected to be registered in Brazil against C. molesta. 


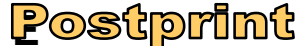

Version définitive du manuscrit publié dans / Final version of the manuscript published in : Journal of Economic Entomology, 2011, vol.104, no.2, 636-645. DOI: 10.1603/EC10302

\section{Acknowledgments}

443 We would like to acknowledge Dr. Stefano Cassanelli from University of Modena and Reggio 444 Emilia for informations and precious advices on the genetic part of this study. We also thank Dr 445 Fabio Molinari for supply of the Italian strain. Finally, we wish to thanks Dr David Biron for critical review and English reading. The authors thank too CAPES (Brazil) for funding the sabbatical grant of L.B. Monteiro at INRA Avignon. 
Version définitive du manuscrit publié dans / Final version of the manuscript published in : Journal of Economic Entomology, 2011, vol.104, no.2, 636-645. DOI: 10.1603/EC10302

\section{References Cited}

Abbott, W. S. 1925. A method of computing the effectiveness of an insecticide. J. Econ. Entomol. 18: 275-277.

Andrei, E. 2009. Compêndio de defensivos agrícolas. $8^{\circ}$ Edição, Andrei Ed., São Paulo, Brazil.

Balachowsky, A. S. 1966. Entomologie appliquée à l'agriculture, Traité 2, Vol 2. Masson et Cie, Paris, France.

Biron, D.G., H.D. Loxdale, F. Ponton, H. Moura, L. Marché, C. Brugidou, and F. Thomas. 2006. Population proteomics: an emerging discipline to study metapopulation ecology. Proteomics 6, 1712-1715.

Boivin, T., J.C. Bouvier, J. Chadœuf, D. Beslay, and B. Sauphanor. 2003. Constraints on adaptive mutations in the codling moth: measuring fitness trade-offs and natural selection. Heredity 90: 107-113.

Botton, M., O. Nakano, and A. Kovaleski. 2000. Exigências térmicas e estimativa do número de gerações de Bonagota cranaodes (Meyrick) (Lepidoptera: Tortricidae) em regiões produtoras de maçã do Sul do Brasil". An. Soc. Entomol. Brasil 29: 633-637.

Bourguet, D., T. Guillemaud, C. Chevillon, and M. Raymond. 2004. Fitness costs of insecticide resistance in natural breeding sites of the mosquito Culex pipiens. Evolution 58: 128-135.

Bouvier, J. C., T. Boivin, D. Beslay, and B. Sauphanor. 2002. Age-dependent response to insecticides and enzymatic variation in susceptible and resistant codling moth larvae. Arch. Insect Biochem. Phys.. 51: 55-66.

Bradford, M. 1976. A rapid and sensitive method for the quantification of microgram quantities of protein utilizing the principle of protein-dye binding. Anal. Biochem._72: 248-254. 
Version définitive du manuscrit publié dans / Final version of the manuscript published in : Journal of Economic Entomology, 2011, vol.104, no.2, 636-645. DOI: 10.1603/EC10302

Brun-Barale A., Bouvier J-C., Pauron D., Berge J-B., and B. Sauphanor. 2005. Involvement of a sodium channel mutation in pyrethroid resistance in Cydia pomonella L. and development of a diagnostic test. Pest Manag. Sci. 61, 549-554.

Cao, G. and Z. Han. 2006. Tebufenozide resistance selected in Plutella xylostella and its crossresistance and fitness cost. Pest Manag. Sci. 62:746-751

Cassanelli, S., M. Reyes, M. Rault, G. C. Manicardi, and B. Sauphanor. 2006. Acetylcholinesterase mutation in an insecticide-resistant population of the codling moth Cydia pomonella (L.). Insect. Biochem.Molecul. Biol. 36: 642-653.

de Lame, F. M., J. J. Hong, P. W. Shearer, and L. B. Brattsten. 2001. Sex-related differences in the tolerance of Oriental fruit moth (Grapholita molesta) to organophosphate insecticides. Pest Manag. Sci. 57: 827-832.

Ellman, G. L., K. D. Courtney, V. Jr. Andres, and R.M. Feather-Stone. 1961. A new and rapid colorimetric determination of acetylcholinesterase activity. Biochem. Pharmacol. 7: 8895.

Fuentes-Contreras, E., M. Reyes, W. Barros, and B. Sauphanor. 2007. Evaluation of azinphosmethyl resistance and activity of detoxifying enzymes in codling moth (Lepidoptera : Tortricidae) from central Chile. J. Econ. Entomol. 100: 551-556.

Guennelon G., H. Audemard, J.C. Fremond, and M.A. El Idrissi ammari. 1981. Progrès réalisés dans l'élevage permanent du Carpocapse (Laspeyresia pomonella L.) sur milieu artificiel. Agronomie. 1: 59-64.

Kanga, L. H. B., D. J. Pree, F. W. Plapp, and J. L. van Lier. 2001. Sex-linked altered acetylcholinesterase resistance to carbamate insecticides in adults of the oriental fruit moth, Grapholita molesta (Lepidoptera : Tortricidae). Pestic. Biochem. Phys. 71: 29-39. 
Version définitive du manuscrit publié dans / Final version of the manuscript published in : Journal of Economic Entomology, 2011, vol.104, no.2, 636-645. DOI: 10.1603/EC10302

Kanga, L. H. B., D. J. Pree, J. L. van Lier, and G. M. Walker. 2003. Management of insecticide resistance in Oriental fruit moth (Grapholita molesta; Lepidoptera : Tortricidae) populations from Ontario. Pest Manag. Sci. 59: 921-927.

Kanga, L. H. B., D. J. Pree, J. L. van Lier, and K. J. Whitty. 1997. Mechanisms of resistance to organophosphorus and carbamate insecticides in oriental fruit moth populations (Grapholita molesta (Busck)). Pestic. Biochem. Phys. 59: 11-23.

Karr, T.L. 2008. Application of proteomics to ecology and population biology. Heredity 100: 200-206.

Kranthi, K. R. 2005. Insecticide Resistance - Monitoring, Mechanisms and Management Manual. Central Institute for Cotton Research, Nagpur, India.

Lorenzato, D. 1988. Lepidópteros nocivos em fruteiras rosáceas no Sul do Brasil. Ipagro 31: 7.

McKenzie, J. A., and P. Batterham. 1994. The genetic, molecular and phenotypic consequences of selection for insecticide resistance. Trends Ecol. Evol. 9: 166-169.

Monteiro, L. B., and A. Souza. 2010. Tortricid moth control in apple with two formulation of Bacillus thuringiensis var. kustaki in fraiburgo, Sc. Rev. Bras. Frutic. 32: 423-428.

Monteiro, L. B., L. L. M. de Mio, A. C. V. Motta, B. M. Serrat, and F. L. Cuquel. 2009. Fluctuation and damage of Grapholita molesta in peach orchards for integrated production in Lapa, Parana, Brazil. Bragantia. 68: 99-107.

Monteiro, L. B., A. de Souza, and L. Belli. 2008. Mating disruption for the control of Grapholita molesta (Lepidoptera: Tortricidae), in Fraiburgo, Santa Catarina, Brazil. Bragantia. 67: 191-196.

Murray, M. G., and W. F. Thompson. 1980. Rapid isolation of high molecular-weight plant DNA. Nucleic Acids Res. 8: 4321-4325. 
Version définitive du manuscrit publié dans / Final version of the manuscript published in : Journal of Economic Entomology, 2011, vol.104, no.2, 636-645. DOI: 10.1603/EC10302

Natale, D., L. Mattiacci, A. Hern, E. Pasqualini, and S. Dorn. 2003. Response of female Cydia molesta (Lepidoptera : Tortricidae) to plant derived volatiles. B. Entomol. Res. 93: 335342.

Nauen, R., and N. Stumpf. 2002. Fluorometric microplate assay to measure glutathione Stransferase activity in insects and mites using monochlorobimane. Anal. Biochem. 303: 194-198.

NedelkovD., U.A. Kiernan, E.E. Niederkofle, KA Tubbs, and R.W. Nelson. 2006. Population Proteomics: The Concept, Attributes, and Potential for Cancer Biomarker Research. Mol. Cell. Proteomics 5: 1811-1818.

Oppenoorph, F. J. 1985. The biochemistry and genetics of insecticide resistance, pp. 731-774.

In: G.A. Kerkut and L.I. Gilbert (eds.), Comprehensive insect physiology, biochemistry and pharmacology Vol. 12. Pergamon Press, Oxford, United Kingdom.

Pree, D. J., K. J. Whitty, L. van Driel, and G. M. Walker. 1998. Resistance to insecticides in oriental fruit moth populations (Grapholita molesta) from the Niagara Peninsula of Ontario. Can. Entomol. 130: 245-256.

Raymond, M. 1985. Présentation d'un programme Basic d'analyse log-probit pour microordinateur. Entomol. Med. Parasitol. 23: 117-121.

Reis, F. W., I. Nora, and R. Melzer. 1988. Population dynamics of Grapholita molesta (Busck, 1916) and its adaptation on apple in south Brazil. Acta Hort. 232: 204-208.

Reuveny, H. and E. Cohen. 2004. Evaluation of mechanisms of azinphos-methyl resistance in the Codling moth Cydia pomonella (L.). Archives of Insect Biochem. Physiol. 57: 92-100. 
Version définitive du manuscrit publié dans / Final version of the manuscript published in : Journal of Economic Entomology, 2011, vol.104, no.2, 636-645. DOI: 10.1603/EC10302

538 Reyes, M., Franck, P., Charmillot, P. J., Ioriatti, C., Olivares, J., Pasqualini, E., Sauphanor, B. 2007. Diversity of insecticide resistance mechanisms and spectrum in European populations of the Codling moth, Cydia pomonella. Pest Manag. Sci. 63: 890-902.

Reyes, M. and B. Sauphanor. 2008. Resistance monitoring in codling moth: a need for standardization. Pest Manag. Sci. 64: 945-953.

Reyes, M., Collange, B., Rault, M., Casanelli, S. and B. Sauphanor. Combined detoxification mechanisms and target mutation fail to confer a high level of resistance to organophosphates in Cydia pomonella L. (Lepidoptera: Tortricidae). Pestic. Biochem. Physiol, in press

Robertson, J. L., K. F. Armstrong, D. M. Suckling, and H. K. Preisler. 1990. Effects of host

Robertson, J. L,. and H. K. Preisler. 1992. Pesticide bioassays with arthropods. CRC Press, Boca Raton, United State.

Roush, R. T., and Jr. F. W. Plapp. 1982. Effects of insecticide resistance on biotic potential of the house fly (Diptera: Muscidae). J. Econ. Entomol. 75: 708-713.

Roush, R. T., and B. E. Tabashnik. 1990. Pesticide resistance in arthropods. Chapman and Hall Ltd. London, UK.,

Russell, R. M., J. L. Robertson, and N. E. Savin. 1977. POLO: a new computer program for probit analysis. B. Entomol. Soc. Am. 23: 209-213.

Sauphanor, B., and J. C. Bouvier. 1995. Cross-resistance between benzoylureas and benzoylhydrazines in the codling moth, Cydia pomonella. L. Pestic. Sci. 45: 369-375. 
Version définitive du manuscrit publié dans / Final version of the manuscript published in : Journal of Economic Entomology, 2011, vol.104, no.2, 636-645. DOI: 10.1603/EC10302

Shi, M.A., A. Lougarre, C. Alies, I. Fremaux, Z. H. Tang, J. Stojan, and D. Fournier. 2004. Acetylcholinesterase alterations reveal the fitness cost of mutations conferring insecticide resistance. BMC Evol. Biol. 4:5.

Siegwart, M., F. Bouvier, S. Maugin and B. Sauphanor. 2010a. Host plant differenciation in french populations of oriental fruit moth, Cydia molesta. IOBC, Working Group "Integrated Protection of Fruit Crops". Vico del Gargano (Italy), 13-17 Sept 2010.

Siegwart, M., H. Coupard, C. Mottet and B. Sauphanor. 2010b. Recrudescence de la tordeuse orientale. Phytoma 633: 28-32.

Smagghe, G., T. S. Dhadialla, S. Derycke, L. Tirry, and D. Degheele. 1998. Action of the ecdysteroid agonist tebufenozide in susceptible and artificially selected beet armyworm. Pestic. Sci. 54: 27-34.

Ulrich, V., and P. Weber. 1972. The O-dealkylation of 7-ethoxycoumarine by liver microsomes: a direct fluorometric test. Physiol. Chem. 353: 1171-1177.

Usmani, K. A., and P. W. Shearer. 2001. Susceptibility of male Oriental fruit moth (Lepidoptera : Tortricidae) populations from New Jersey apple orchards to azinphosmethyl. J. Econ. Entomol. 94: 233-239.

Varela, L. G., P. W. Shearer, 1997. Monitoring of insecticide resistance in Phyllonorycter mespilella (Lepidoptera: Gracillariidae) in four western states. J. Econ. Entomol. 90: 252260.

Waldstein, D. E., and W. H. Reissig. 2000. Synergism of tebufenozide in resistant and susceptible strains of obliquebanded leafroller (Lepidoptera : Tortricidae) and resistance to new insecticides. J. Econ. Entomol.93: 1768-1772. 


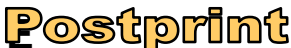

Version définitive du manuscrit publié dans / Final version of the manuscript published in : Journal of Economic Entomology, 2011, vol.104, no.2, 636-645. DOI: 10.1603/EC10302

582 Yasutomi, K. 1983. Role of detoxification esterases in insecticide resistance. Plenum Press, New York, USA.

584 Zhu, K. Y., and J. R. Gao. 1999. Increased activity associated with reduced sensitivity of acetylcholinesterase in organophosphate-resistant greenbug, Schizaphis graminum (Homoptera : Aphididae). Pestic. Sci. 55: 11-17. 
Version définitive du manuscrit publié dans / Final version of the manuscript published in : Journal of Economic Entomology, 2011, vol.104, no.2, 636-645. DOI: 10.1603/EC10302

Table 1: Susceptibility to five insecticides of neonate larvae of one reference strain $\left(\mathrm{S}_{\mathrm{it}}\right)$ and three Brazilian populations (Vacaria, Porto, Lages) of C. molesta.

\begin{tabular}{|c|c|c|c|c|}
\hline Insecticide & Population & $\mathbf{N}^{2}$ & $\mathrm{LC50}^{3}(95 \% \mathrm{CL})$ & $\begin{array}{c}\text { LC50 susceptibility } \\
\text { Ratio } / \mathrm{S}_{\text {it }}{ }^{4} \\
\end{array}$ \\
\hline \multirow[t]{4}{*}{ Chlorpyriphos } & $\mathrm{S}_{\mathrm{it}}{ }^{1}$ & 168 & $92.53(40.70-177.44)$ & \\
\hline & Vacaria & 168 & $276.17(171.28-568.68)$ & $2.98(2.23-3.99)$ \\
\hline & Porto & 165 & $272.44(151.62-829.76)$ & $2.94(2.24-3.87)$ \\
\hline & Lages & 161 & $250.17(134.35-814.38)$ & $2.70(2.06-3.54)$ \\
\hline \multirow[t]{4}{*}{ Deltamethrin } & $\mathrm{S}_{\mathrm{it}}$ & 164 & $0.13(0.10-0.18)$ & \\
\hline & Vacaria & 167 & $0.24(0.17-1.72)$ & $1.80(1.16-2.79)$ \\
\hline & Porto & 166 & $0.12(0.10-0.13)$ & $0.88(0.69-1.12)$ \\
\hline & Lages & 164 & $0.12(0.11-0.14)$ & $0.90(0.75-1.09)$ \\
\hline \multirow[t]{4}{*}{ Thiacloprid } & $\mathrm{S}_{\mathrm{it}}$ & 190 & $91.30(72.60-108.46)$ & \\
\hline & Vacaria & 165 & $55.98(17.57-78.65)$ & $0.61(0.42-0.90)$ \\
\hline & Porto & 168 & $39.39(22.60-53.05)$ & $0.43(0.30-0.62)$ \\
\hline & Lages & 166 & $86.16(66.92-110.40)$ & $0.94(0.67-1.34)$ \\
\hline \multirow[t]{4}{*}{ Tebufenozide } & $\mathrm{S}_{\mathrm{it}}$ & 165 & $9.44(7.18-10.94)$ & \\
\hline & Vacaria & 166 & $9.30(5.44-11.62)$ & $0.98(0.71-1.36)$ \\
\hline & Porto & 188 & $8.15(3.71-46.10)$ & $0.86(0.61-1.23)$ \\
\hline & Lages & 191 & $4.55(2.99-7.49)$ & $0.48(0.36-0.64)$ \\
\hline \multirow[t]{4}{*}{ Carbaryl } & $\mathrm{S}_{\mathrm{it}}$ & 191 & $165.3(120.3-227.6)$ & \\
\hline & Vacaria & 189 & $237.3(181.2-312.8)$ & $1.44(1.00-2.08)$ \\
\hline & Porto & 186 & $190.0(120.7-229.9)$ & $1.15(0.77-1.71)$ \\
\hline & Lages & 188 & $144.4(108.2-192.4)$ & $0.87(0.58-1.32)$ \\
\hline
\end{tabular}

${ }^{1} \mathrm{~S}_{\mathrm{it}}$ - European reference strain mass-reared on artificial diet since over 10 years.

${ }^{2}$ Number of neonates tested.

${ }^{3} \mathrm{LC}_{50}$ values expressed in $\mathrm{mg} \mathrm{L}^{-1}$.

${ }^{4}$ Susceptibility Ratio/ $/ \mathrm{S}_{\mathrm{it}}$ : Resistance ratio $=\mathrm{LC} 50$ of Brazilian strain divided by LC50 of the reference strain. 
Version définitive du manuscrit publié dans / Final version of the manuscript published in : Journal of Economic Entomology, 2011, vol.104, no.2, 636-645. DOI: 10.1603/EC10302

Table 2: Acetylcholinesterase inhibition by Carbaryl in adults of four populations

of C. molesta.

\begin{tabular}{lllllll}
\hline Populations & Sex & $\mathbf{n}^{\mathbf{a}}$ & Slope \pm SE & $\left.\mathbf{I C}_{\mathbf{5 0}}^{\mathbf{b}} \mathbf{( 9 5 \%} \mathbf{C I}\right)$ & $\left.\mathbf{I R}^{\mathbf{c}} \mathbf{( 9 5 \%} \mathbf{C I}\right)$ & $\boldsymbol{\chi}^{\mathbf{2}}$ \\
\hline \multirow{3}{*}{$\mathrm{S}_{\text {it }}$} & Male & 25 & $1.03 \pm 0.07$ & $0.012(0.009-0.015)$ & & 3.8 \\
& Female & 25 & $0.84 \pm 0.06$ & $0.008(0.006-0.011)$ & & 1.7 \\
Vacaria & Male & 25 & $1.15 \pm 0.07$ & $0.012(0.010-0.015)$ & $1.0(0.9-1.2)$ & 3.9 \\
& Female & 25 & $1.00 \pm 0.07$ & $0.011(0.009-0.014)$ & $1.7(1.2-1.5)$ & 4.3 \\
Porto & Male & 25 & $1.21 \pm 0.09$ & $0.017(0.014-0.022)$ & $1.5(1.3-1.7)$ & 1.8 \\
& Female & 25 & $1.07 \pm 0.07$ & $0.016(0.012-0.020)$ & $1.9(1.7-2.1)$ & 1.7 \\
Lages & Male & 25 & $1.15 \pm 0.06$ & $0.019(0.015-0.024)$ & $1.6(1.5-1.8)$ & 2.9 \\
& Female & 25 & $1.06 \pm 0.07$ & $0.021(0.016-0.027)$ & $2.5(2.2-2.8)$ & 4.6 \\
\hline
\end{tabular}

${ }^{\mathrm{a}}$ Number of adult month tested.

${ }^{\mathrm{b}}$ Concentration are expressed in $\mathrm{mmol} / \mathrm{min} / \mathrm{mg}$ of protein for Carbaryl.

${ }^{\mathbf{c}} \mathrm{IC}_{50}$ s estimated by probit analysis; inhibition ratio IR calculated by dividing the $\mathrm{IC}_{50}$ for the Brazilian populations (Lages or Porto or Vacaria) by the $\mathrm{IC}_{50}$ for our laboratory strain $\left(\mathrm{S}_{\mathrm{it}}\right)$ for each gender. 
Version définitive du manuscrit publié dans / Final version of the manuscript published in : Journal of Economic Entomology, 2011, vol.104, no.2, 636-645. DOI: 10.1603/EC10302

\section{Figure Legends}

Figure 1: (a) Glutathion S Transferase activity, measured in fluorescence unit formed $/ \mathrm{min} / \mu \mathrm{g}$ of protein, in reference strains $\left(\mathrm{S}_{\mathrm{it}}\right)$ and Brazilian strains (Vacaria, Porto and Lages) of the oriental fruit moth. (b) Carboxylesterase activity, measured in nmoles of product ( $\alpha$-Naphtol or pNitrophenol)/min/mg of protein. Letter (Capital one for esterase activity with p-NA and small letter for GST or esterase activity with $\alpha-\mathrm{NA})$ illustrate Tukey test ( $\mathrm{p}>0.05)$. (c) Acetylcholine esterase activity, measured in nmoles of acetylthiocholine/min/mg of protein, in reference strains $\left(\mathrm{S}_{\mathrm{it}}\right)$ and brazillian strains (Vacaria, Porto and Lages) of the oriental fruit moth. Letter illustrate Tukey test $(\mathrm{p}>0.05)$.

Figure 2: Distribution of MFO activities (pg of 7-HC/min/abdomen of insect) by populations and sex. 


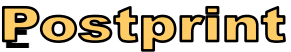

Version définitive du manuscrit publié dans / Final version of the manuscript published in : Journal of Economic Entomology, 2011, vol.104, no.2, 636-645. DOI: 10.1603/EC10302

a)

Figure 1

621

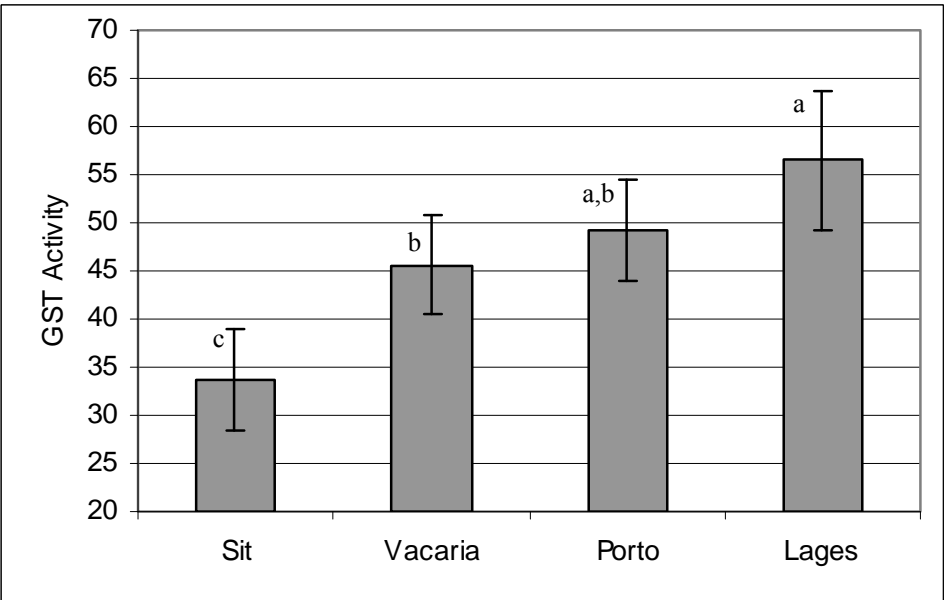

b)

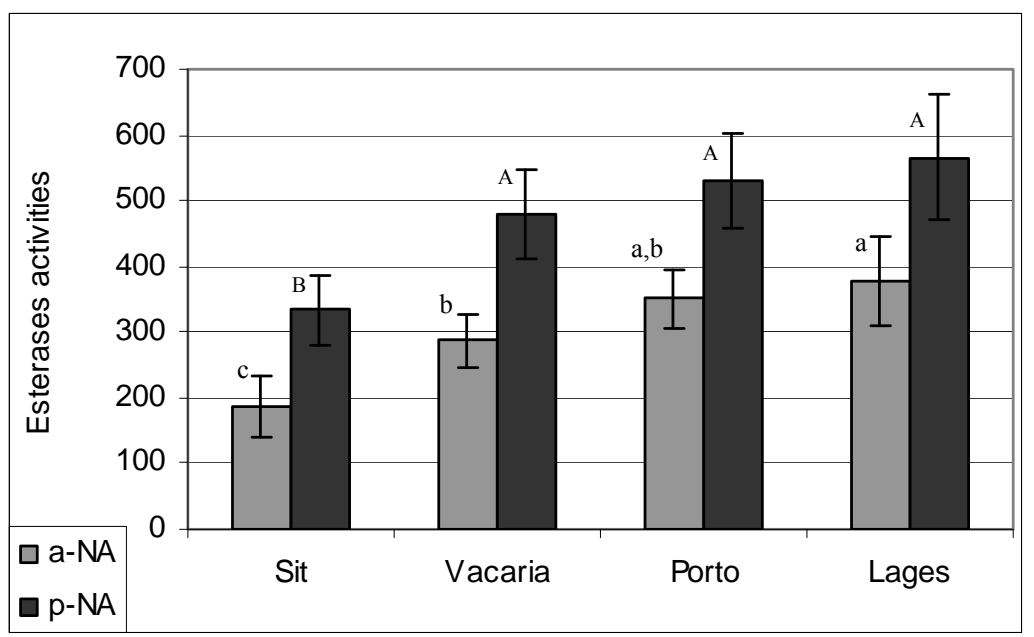




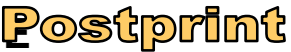

Version définitive du manuscrit publié dans / Final version of the manuscript published in : Journal of Economic Entomology, 2011, vol.104, no.2, 636-645. DOI: 10.1603/EC10302

c)

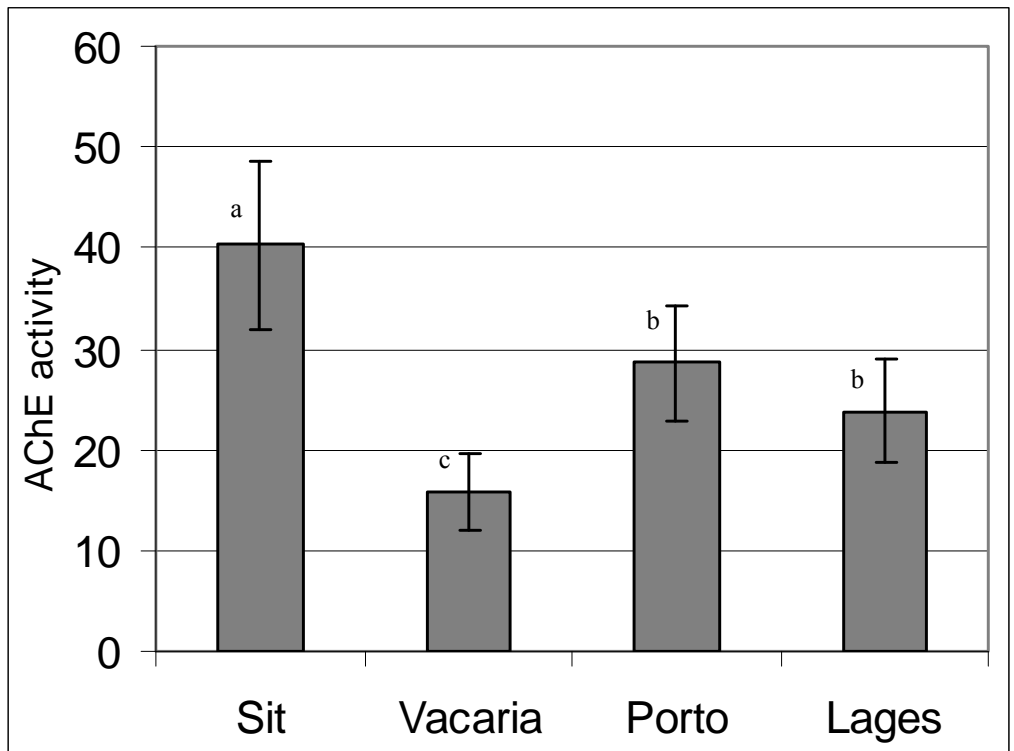




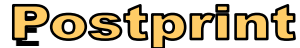

Version définitive du manuscrit publié dans / Final version of the manuscript published in : Journal of Economic Entomology,

2011, vol.104, no.2, 636-645. DOI: 10.1603/EC10302

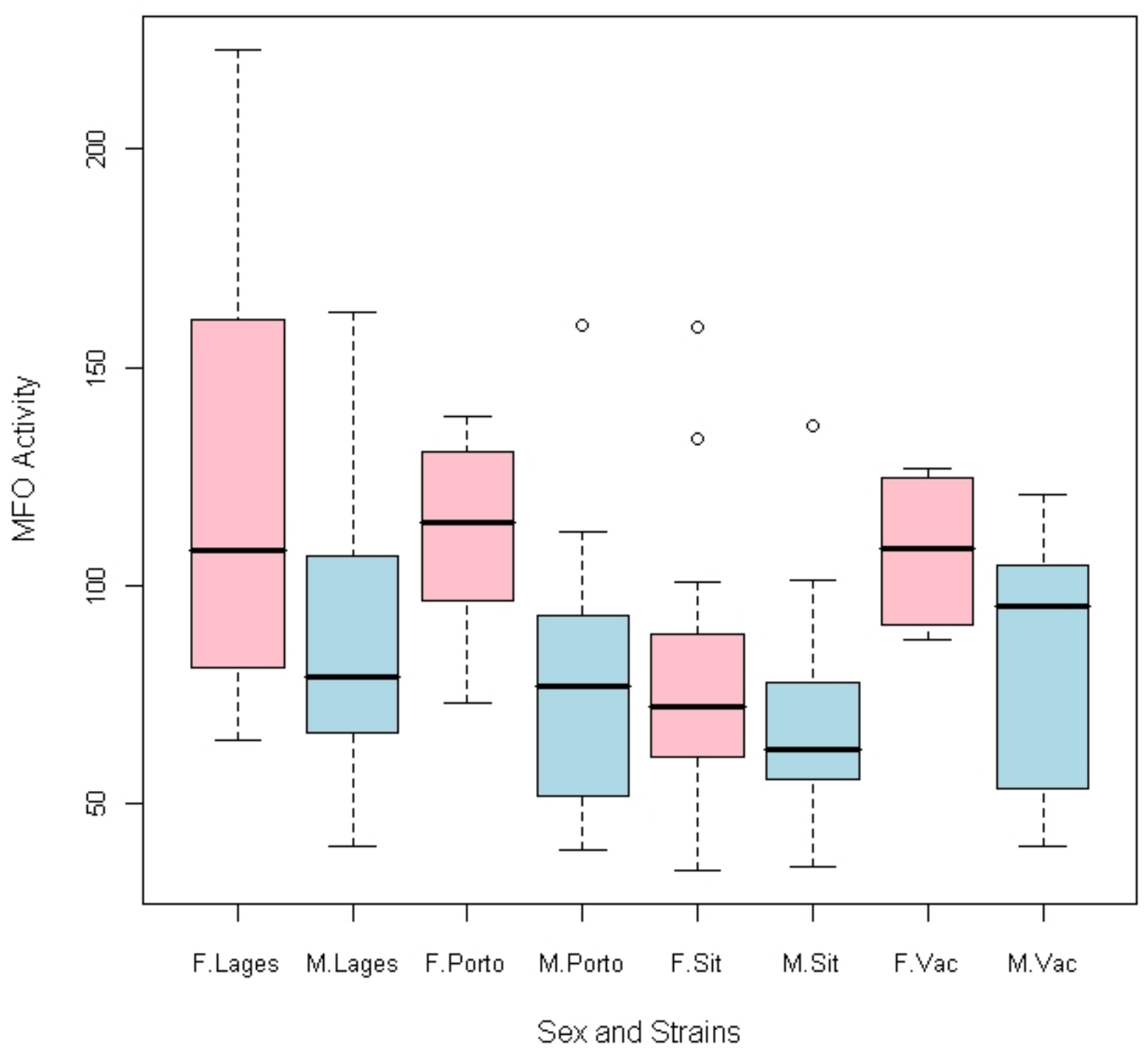

